\title{
Surfaces
}

\section{HUMANISM AS ANTI-IDEOLOGY}

\section{Alexander K. Gavrilov}

Volume 9, 2001

TROISIÈME CONGRÈS INTERNATIONAL SUR LE DISCOURS HUMANISTE. LA RÉSISTANCE HUMANISTE AU DOGMATISME AUJOURD'HUI ET À LA FIN DU MOYEN ÂGE THIRD INTERNATIONAL CONFERENCE ON HUMANISTIC DISCOURSE. HUMANISTIC RESISTANCE TO DOGMATISM TODAY AND AT THE END OF THE MIDDLE AGES

URI : https://id.erudit.org/iderudit/1065064ar

DOI : https://doi.org/10.7202/1065064ar

Aller au sommaire du numéro

\section{Éditeur(s)}

Les Presses de l’Université de Montréal

ISSN

1188-2492 (imprimé)

1200-5320 (numérique)

Découvrir la revue

Citer cet article

Gavrilov, A. K. (2001). HUMANISM AS ANTI-IDEOLOGY. Surfaces, 9.

https://doi.org/10.7202/1065064ar

\section{Résumé de l'article}

En régime communiste, l'idéologie du parti et les valeurs humanistes entraient en conflit. Dans l'analyse de ce conflit, l'auteur souligne les ressources théoriques et les grands avantages politiques de l'humanisme. Le communisme était victime de son hypocrisie travestissant la généralité de l'aphorisme " L'homme est bon » dans le particulier « Les hommes vivant dans le communisme sont bons ». Cependant, le socialisme scientifique et les politiques que l'État en a tirées ont eu pour effet de faire du pays une grande salle de lecture où les humanités, et parmi celles-ci la philologie, jouissaient d'une grande popularité. La philologie, comme outil de l'étude du style, est essentiellement à l'épreuve de l'idéologie. Plutôt que de développer des contre-idéologies, plusieurs Russes ont choisi une résistance active passive préférant utiliser les formes de l'ironie que les humanités cultivaient. Cette praxis d'érosion graduelle de l'idéologie dominante en soi-même et dans son environnement était nécessaire à ce qui allait devenir la perestroika. L’humanisme a prouvé qu'il était, dans la nécessité, un merveilleux opposant à l’idéologie.
Copyright (C) Alexander K. Gavrilov, 2001

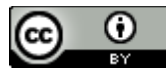

Ce document est protégé par la loi sur le droit d'auteur. L’utilisation des services d’Érudit (y compris la reproduction) est assujettie à sa politique d'utilisation que vous pouvez consulter en ligne.

https://apropos.erudit.org/fr/usagers/politique-dutilisation/ 


\title{
HUMANISM AS ANTI- IDEOLOGY
}

Alexander K. Gavrilov

Surfaces vol IX 101.4 (v1.0a - 15.12.2001) - ISSN: 1188-2492

Tout texte reste la propriété de son auteur. Néanmoins, SURFACES demande d'être citée à l'occasion de toute autre publication du texte en question.

\begin{abstract}
Under Communist rule, Party ideology and humanistic values conflicted with one another. In analysing this conflict, the author underlines the theoretical resources and the great political assets of humanism. Communism was afflicted by its hypocrisy moving from the general the "Man is good" to the particular the "Men living in communism are good". However, scientific socialism and its state politics changed the country into a great reading hall where humanities, and among them philology, became very popular. Philology, as a tool in the study of style, is essentially ideology-proof. Rather than developing counter-ideologies, many Russians turned to an active passive resistance through uses of irony that the humanities cultivated. This praxis of gradually eroding the dominant ideology within oneself and one's environment was necessary to what would become perestroika. Humanism has proven to be, under necessity, a marvelous opponent of ideology.
\end{abstract}

\section{RÉSUMÉ}

En régime communiste, l'idéologie du parti et les valeurs humanistes entraient en conflit. Dans l'analyse de ce conflit, l'auteur souligne les ressources théoriques et les grands 
avantages politiques de l'humanisme. Le communisme était victime de son hypocrisie travestissant la généralité de l'aphorisme « L'homme est bon » dans le particulier « Les hommes vivant dans le communisme sont bons ». Cependant, le socialisme scientifique et les politiques que l'État en a tirées ont eu pour effet de faire du pays une grande salle de lecture où les humanités, et parmi celles-ci la philologie, jouissaient d'une grande popularité. La philologie, comme outil de l'étude du style, est essentiellement à l'épreuve de l'idéologie. Plutôt que de développer des contre-idéologies, plusieurs Russes ont choisi une résistance active passive préférant utiliser les formes de l'ironie que les humanités cultivaient. Cette praxis d'érosion graduelle de l'idéologie dominante en soi-même et dans son environnement était nécessaire à ce qui allait devenir la perestroika. L'humanisme a prouvé qu'il était, dans la nécessité, un merveilleux opposant à l'idéologie.

Previous discussions about the term "humanism" - a quasi-material vehicle of a complex notion taking its origin in the golden periods of West-European culture have already produced some cogent results. Classical Rome, as a majestic exponent of Hellenistic ideas and ideals of humanitas, and Italy, as an exponent of umanisti with its Revival of the Italian classical past, were as necessary for its coming into existence as Germany was for the epoch later called Neuhumanismus to mark the creative assessment of archaic and classical Greece. It was here that the German word Humanismus was born, to be accepted without much ado by all cultivated languages. The fact is neither accidental nor as simple as the linguistic form of this neologism may suggest. The idea that crystallized into this new word was not focused in vain, but only after long disputes, on the Humanität . It was the reaction of Europe to the Enlightenment and to the French Revolution, as a thoughtful answer to a great challenge. The notion of humanism came forth in the extraordinarily creative atmosphere of complex new 
inquiries about political, literary, philosophical, educational and religious values.

Notwithstanding these happy circumstances - or just thanks to them - humanism remains something so variegated that very often doubts are put forth as to its message. Even the unity of its meanings is questionable: a certain compassionate attitude to the dire necessities of human beings all over the world, a not clearly defined moral system or literary culture with reference to a certain epoch or without such a reference. Moreover, if one tries to make all bearings of humanism explicit in good faith, so that there is something important behind the name, various, even opposite, ideas appear to the observer.

Are the men and women seen by the eyes of humanists good or bad? In spite of the readiness to help those who suffer from extreme privations, or the disposition to applaud the highest achievements of mankind, humanism does not seem to be very enthusiastic about the majority. Neither is it inclined to idealize even demonstrably good people, tending rather to be suspicious of their absolute integrity and counterbalancing the virtues even of its heroes with some doubtful traits. Philanthropy and misanthropy seem therefore to go hand in hand within the humanistic discourse and one never knows, which of the two will prevail. Democratic in procedure and elitist in its aims, humanism prefers to see an exemplary human being in persons extraordinary; it is a kind of perpetual Olympic committee on a universal scale of human distinction in endeavors much less discernible than those of the human body.

Humanism is, further, a culture of the culture, its own self-conscience. At the same time the humanist spirit seems to indulge in the cult of the genius, which is one of the greatest triumphs of human nature. Now, what is more important for humanism: Kultur or Natur? To give one more example of humanistic inconsistencies: is humanism a decent way to profess atheism or does it decide the quest for God positively? We come to no unequivocal answer to this question either: both humanistic agnosticism and Christian humanism are well attested.

Nevertheless, there is obviously something more solid and valuable in humanism than a chaotic description of human types and a record of various achievements respectively, misdeeds under a tautological motto: human beings are exactly what human beings areand 
nothing else. How, then, could this contradictory and apparently incoherent notion, called humanism, claim to be of importance in the issues of humanity?

\section{2.}

The phenomenon of ideology is also an old and ubiquitous one despite the fact that the word itself originated in France on the same late date as the word 'humanism', just to be greeted scornfully by Napoleon. The importance of the notion of 'ideology' is twofold. Power needs to be rationalized in some way to win the support of the population. To find a place in the sun, ideas or systems of ideas tend to seek the support of power. It is ideology in power, that is ideocracy imposing its dogmas as obligatory and exclusive within the whole state, which will interest us here. The features I will describe (I will take Russia as an example because I know it from long experience) can be observed in Russia during the second half of the Soviet period. This period was not as young and violent as the first one. There was an ugliness and a charm of decay in it. It was a time of the falling tide, with suppressed memories and many an enigmatic trace of the dire ebb.

The fact that ideology was essential for the very existence of the system it was responsible for was never concealed by the Communist Party. Just the opposite took place: the "ideological war" was led within and outside the country. The feeling that ideology had lost its importance in the late Soviet period because its exponents did not religiously comply with the values proclaimed in the dogma came from the liberal opposition. The evaluation was false in spite of appearances. According to Solzhenitsyn the dead kept their hold on the living with a deadly grip. The superjournalist of Russian letters was right: the proclaiming of an ideology is not an accidental and inane act; many decisions, dangerous for the subsistence of the Communist Party, were (and are) arrived at only because they conformed to the party line.

We have seen it even during the last elections: had it not been for its obsolete and preposterous ideology, the Communist party of the Russian Federation could have regained much more of the political terrain. But having once proclaimed an exclusive ideology, the dogmatist stands before a choice: either to change a front and lose the legitimacy for the former predominance or to remain true to the principles which have lost their charm and lose the battle. 
To some degree an addiction to ideology is fatal, because as such it presents ideas that lie far from political wisdom and common sense; ideology becomes a kind of ideal political boomerang.

\section{3.}

We have our dramatis personae before us: one humanism - so evasive, complex, seemingly now contradictory, now tautological; in spite of its learned provenance it remains so uncertain as to its origins and its claims, that the question arises whether there is such an entity as humanism at all. On the other hand, we have clear-cut ideology, imposing through its association with power, possessing canonical texts of its own; its "short history" is already there at its antenatal period, showing off some nice genealogy in the realm of human thought. What can ideas linked to no regular, if any, doctrine have in common with a system of appealing theses brought together deftly for the sake of consistent indoctrination?

\section{II.}

1.

The experience reveals to us, however, that there is such common ground for ideology and humanism, even if it is seldom perceived at first sight. What were the basic claims of Marxist ideology in early Soviet Russia? It was, for example, the coming of world revolution: a prophetic view of this eschatological change during the Cold War became rather a dim pretext for the Realpolitik of world power. Take another thesis, thought to be important within the framework of so-called historical materialism: matter is primary; conscience is secondary. Well, what's the difference? A significant element in those principles - besides regulations concerning power and property was some idea of mankind, that is, of men and women, which was announced directly by this new orthodoxy or lay behind it.

For Marx himself the basic importance of this section in his reasoning was clear as he spoke with delight of the Menschenbild that was implicitly present in his theories. His main concern was to refute the Entfremdung and to design a society in which the natural and the social, Wesen and Existenz, in man become one at last. 
Running this course we come to socialist humanism one of the peculiar idioms of the lingua imperii communistici (LIC?) - which by itself reveals the sphere where Party ideology and humanistic values could not help but come into conflict. You know the happy end of the story: the latter proved its effectiveness in the struggle against the former. My task will be to analyze some aspects of this pretty long story and to demonstrate the serious theoretical resources and the great political assets of humanism.

Communist ideology was far from being notably tolerant of criticism; its enemies were inside and outside of the country, practically everywhere. All the more remarkable was the overall Marxist statement that man is good (cp. Genesis 1:31). As a thesis of socialist orthodoxy this seemed somewhat unexpected, but it becomes more comprehensible if one considers that the goodness of people and the adherence to ideology are one and the same. In a more overt way it sounds like (only) men living in socialism are good. Socialist humanism that had a counterpart in letters called socialist realism should not represent man as a poor being lost among difficult problems or even insoluble ones. Everything censured as abnormal in private life had to be expelled from art and conceived as life's judiciously true reflection: all deviations, perplexing sexuality, the problems of children and parents, even stupidity, to say nothing of political issues, were to be brought into line with the ideas and the ideals prescribed by the leaders of socialist society.

Let us take some other seemingly don-quixotic features declared by soviet ideology. The psychological needs of those who could not aspire to much dignity otherwise were supported ideologically: the 'working people' were (theoretically) regarded as important members of socialist masonry. All constructors of socialism (the whole population except the enemies of the people and the outcasts) were more than progressive - they were defenders of the scientific outlook. The government was really eager to give everyone what we now perceive to be a decent high-school education: the (partly true) premise was the idea that (semi-)educated people should become willing recipients of the communist kerygma. It was the elitist humanistic education that was underprivileged in Soviet time - the point demonstrating the political shrewdness of Party dictatorship, limited (only) by their own ideological dogmas.

The social groups with poor education were proclaimed to possess well-differentiated opinions of what is right or 
wrong in human society, that is, they were meant to profess naturaliter the communist dogma as well as to applaud the current resolutions of the Soviet government. The flattery was not totally new - it had a touch of romanticism (conservative or revolutionary) of the XIX century. Those working in the industry were now called "hegemon(s)" not only by the press, but ironically - by the people on the streets. The predestined bearers of the conceited ego of K. Marx seemed to be neither flattered nor unhappy with this situation: they could take it as a sign that they were at least in some sense equal to the "spectacle-bearers". They saw, however, that the leaders of the country did not obey their own rules, but they felt at the same time that those leaders were their elite, not those of the intelligentsia. So the old resentment - and who may deny that this was groundless in old Russia? - was balanced at least by this feeling of absolute innocence and the fundamental righteousness of the majority.

Women were another case of communist ideological gallantry. They did not achieve much within Party leadership. But there was an elite of women almost everywhere in the cultural sphere. Women prevailed as high school teachers and in the field of medicine. In the Universities humanities seemed to be a sort of Mädcheninstitute where women taught women. The idea that a man worked to earn money for his family was perhaps not entirely forgotten, but it was absolutely impractical. The women generally had the same sort of jobs and received the same (poor) salary (to be fair, it should be added that this was more or less sufficient for a frugal existence). There were no other means for women to achieve greater income. The system was physically difficult for women and psychologically difficult for men who thus became the weaker part of the family. As a result both sexes felt nearly equal. Those who find this to be a welcome goal of the social process should know that it was already achieved to a high degree in the Soviet Union.

But it is not this state of affairs that I wanted to relate here. The topic of my present deliberations was the ideological bias in depicting women in letters and in art advantageously regarding high human qualities. A woman was considered an especially nice creature, a thoughtful bride, and an ever-devoted mother. She was meant to be the pattern of integrity within the (socialist) society. Since "there was no sex in the Soviet Union" (as the official position was once stated by a conformist but imprudent official), the socialist woman was a socially relevant partner in the family or in a charmingly pure 
love story - just the opposite of the concupiscent witches of the Middle Ages and their ideology.

2.

At the same time the fundamental freedom of human beings in the intellectual sphere was denied not only at present and within the country of the communist experiment, but also for whatever historical epoch. These were all judged to stay not unmittelbar vor Gott, but before the tribunal of Soviet ideology. The verdict was chronically, even if sometimes mildly, negative. The latter took place in cases, where the person or situation in question was considered an imperfect predecessor of anything approved by the Soviets. The time after the Great October revolution was the acme of perfection other epochs could only aspire to, a kind of mathematical limit for the sequence of innumerable revolts and revolutions. All other recorded events (with the notable exception of the history of science) were presented rather indifferently, if at all. Even the historical persons approved by ideology and praised by Soviet art, such as Spartacus or Robespierre or such characters as the Gadfly of Voinich, were a bit despicable as they had not had the privilege to read (or not to read) the tiresome works of K. Marx or the papers of Uljanov, of which, I daresay, only the shooting orders were read as they had been meant to. The progress of a revolutionary idea like the Homeric Ate was beyond the scope of the poor, not yet Leninist, heads of human beings. Everybody and everything before Marx and Engels was "historically limited", as the current idiom of the period used to put it.

To say 'long ago' the colloquial style could use the locution "before the historical materialism". A girlfriend speaking of the time when she had not known her lover could say, "Then, you know, before the historical materialism". . .

Writers were defined by our ideologues, further, as exponents of their social class. The founding fathers themselves, who regrettably did not originate from the families of steelworkers or milkmaids, were the only honorable exceptions. This method of teaching world history (who did not understand what) was practiced massively in the high schools producing a deep ignorance of world history along with a definite feeling of the mediocrity of an ideology that needs to castrate past generations. The soviet critics used to conclude their critical surveys in such a manner: "Though so-andso was not able to comprehend clearly ... ." It remained 
unclear why so-and-so was a great man, while nobody had the slightest doubt that a critic was not. It was not the only way to castigate or edify the bygone epochs. Along the lines of the principle of the changeability of the past, discovered by Orwell (with that chiseled irascibility British authors arrive at so brilliantly), the dutiful orthodoxy made censorship retrospective and allowed the regular selection of the Complete Works of those authors who were permitted to remain historical.

The idea that man was conscious of the problems within his own community was restricted in Soviet letters mostly to the Soviet citizen, while the collective image of those who had lived in the perished ancient world or in the perishing capitalist world, had to suggest individualism and therefore drastic social irresponsibility. The Third World was - perhaps rightly so - regarded as a limbo lying nearer to the scientific outlook. The class struggle was everlasting and should remain so until the inevitable victory of communism. This was the scientific outlook. This was a wellarticulated invitation to civil discord, based allegedly on the nature of man and on the nature of human society.

With respect to the men of letters who happened to be under the protection of the state, the generosity of the paternalist ideology consisted in the expurgation from literary works and biographies of everything held to be inconvenient or conceived to bring disrepute upon the promulgated author. Along with such non-persons as émigré writers (for instance, Ivan Bunin), there were (since the 1930's) adapted and bowdlerized biographies of many Russian writers and artists; the truth was conceived as seriously damaging to the expected political benefits of their artistic influence. The faults of these great men should not scandalize the frail homo sovieticus or even produce irregularities in his conduct. It is not in vain that the most classical of human vices were tiresomely styled as 'survivals of the past'.

The suicide of the president of the Soviet Writers Union in the 50's, prose-writer A. Fadeev, plagued by Party censorship, was not, for example, admitted publicly as such. A case of alcoholism was officially declared because suicide was disapproved in principle: it was better to be a drunkard than an outcast (the motivation was not insulting the good God, but an insult to the unique society). As a matter of fact Fadeev seems to have been flexible enough, but the demands of ideology were insatiable. 


\section{3.}

Frugality, modesty, work, sense of duty, generous dislike of suppression in the social or national sphere (above all in countries other than their own), the friendly attitude toward other national cultures - these were rather sympathetic features proclaimed as the Soviet human ideal.

On the whole this image of the would-be homo sovieticus impressed more or less positively, though this sanctified picture was evidently ingenuous. There was, I suppose, an essential support for this borrowed from the Russian Orthodox Church, which was almost destroyed by the Bolsheviks. Especially those ideas of primitive Christendom, which evidently had a stronghold on Russian tradition: eschatology, messianism, life within a village community, and an innermost devotion to equality in poverty along with a marked indifference to culture and individual achievement. Since Peter the Great, blind obedience to the state became a habit. These attitudes produced benefits in Russia as well as some evils. Since there are always simple (and noble) hearts, which act in accordance with the most arduous principles, I do not affirm, all the same, that the human being projected by Marxism did not ever come into existence.

In the present context popular comparisons of communism and fascism may affirm that the anthropological message of communism was not as conspicuously evil as that of the Nazis: on the contrary, it made a rather somewhat utopian, but benign impression. Communism fixed attention on the unity of mankind and on the more radiant sides of human nature; it did not extol - at least overtly - its darker traits. The soviet xenophobia, for example, was rather political, not zoological. Putting the question generally: is the open declaration of evil principles better or worse than the hypocritical proclaiming of humane ones? The answer is not easy. The former is more resolute and must be wiped out more resolutely; the latter has a creeping nature and makes the system more dangerous than it seems to be.

Both in the case of doctrinaire criticism and moral patronage, the Party line devoted to the creation of a new human image, went far beyond the reasonable borders of public order. It insulted the human desire for truth and the human right to know a consistent history of people and nations. The didactic vein, obvious in all these practices, was partly based on out-of-date tastes and utopian impulses, but these were accidental. Not accidental was the premise, which remained 
unexpressed directly: historical man was unacceptable to the new system. The expedient education was unable to make him sufficiently fit for it. The task of reeducation became a priority for the Bolsheviks (even in today's Russia, this word displays an association with the penitentiary system). A "human being of the new type" was proclaimed a grandiose aim, parallel to the "transformation of Nature", not as a sad by-product of industrialization, but as a cosmic pursuit, an act of rivalry of Man with Nature. This Promethean scheme to transform both of them was an experiment, authorized only by Party ideology and was led in the huge country by whatever devices were found necessary.

An anecdote about the possibility of introducing linguistic change on the phonetic level as a question of means and administrative measures is admissible for its accomplishment.

\section{III.}

\section{1.}

Let us look now on humanism and humanities under the aspect of their ideas about the nature and destiny of mankind. Humanities are an immense field of knowledge, where human affairs as well as persons are studied first, though not exclusively, through literary sources. The sphere of belles lettres (especially fiction) despite its allegedly non-historical character, is one of the most complex and rich documents about the nature of human beings. Philology, according to its matter-offact definition, studies and explains texts in order to preserve them for present and future generations. Do humanities and humanism have much in common except the proximity of their names in alphabetical dictionaries? Were the humanists with their sometimes ludicrous passion for ancients and antiquities, named this way in vain?

I think not. A man (or a woman) chooses humanities as he (or she) feels an overpowering urge to observe his (or her) own (human) kind throughout history. This desire is accepted by society as it corresponds to the wish of the latter to know details about previous generations. The wish to know some history is understandable in a rapidly changing world on the one hand, and rich enough to sustain this service of human record on the other. 
Documentation du présent is one of the maturest byproducts of this endeavor: even actuality is conceived here as a part of the past in the future. But only those people or societies who lived full lives and possess both ante quos and post quos can be fully evaluated. One can scientifically measure the man of the actual time. Only generations long past can form a basis for a thorough acquaintance. The Herodotean idea associated later with the Latin respice finem retains its well-tested force.

The study of European classics especially Greek and Roman classical civilization is therefore not based on cultural prejudice such as European cultural vanity. As a matter of fact it is only fair to give attention to the most cultivated nations of the past; an attention paid by the ever growing and almost universal highly cultivated modern community. The scholarly assets accumulated thus during the centuries are unparalleled. It is this double potential of the classical subject and classical methods, as well as results of investigations that explain why classical philology is the pearl of the humanities (q.e.d.). Together with other possibilities the richness of classical sources gives humanity a chance to arrive at the historic dimension of anthropology - one of the many until now half latent capacities of classical philology.

\section{2.}

Are there some links between out-of-the-way scholarship in ancient things - apparently the most bookish part of humanities - and modern ideological debates? Since we have fixed some points of contact between ideology and humanism, despite their apparent incongruence, we can give some hints here as to the battles that were fought in Soviet society before the fall of communist totalitarian ideology, causing its downfall to a certain degree. Man's nature is good (but only the communist system is capable of putting this goodness into effect). Seen as the background of the eternal problems of humanity which haunt the memory of men, the initial (and overt) part of the thesis was obviously too good to be true. The image of man presupposed by the "Moral code of the constructor of communism" - this premature socialist decalogue - was stillborn from the beginning. As to the negative implication of the same thesis - societies other than communist-oriented ones should be incapable of producing any human excellence - the world of history and letters, beginning with classical antiquity, exposed its falsehood and even held it up to derision automatically. 
V. Nabokov tells us about a strong proletarian hand, which generously stretched to him from the wagon as he bravely tried to catch up with the train after saving his luxurious stick; we have Fellini's half-naked firemen hearing the competition of the star tenors in the machine section of the Nave.

The woman, we have discovered in western especially Anglo-Saxon literature - often depicted as wicked, craving for lust and power, sometimes substantially dishonest with the tendency to manipulate men - was a (somewhat pornographic) revelation. Along with insoluble psychological problems of love and marriage those works of literature made the serene picture of socialist realism (respective of the new humanism) much less convincing. Boccaccio, Flaubert, and The Widow of Ephesus found not only masculine, but also anthropological interest. I think that an importation of alien patterns through cinema and reading was all the more extensive since there had been no private initiative and relatively poor chances even in professional activity. It was a very important stage in the process of emancipation from the patterns of human conduct ordered or suggested by Party authorities through art, minutely and industriously promoted by state ideology.

These are examples of the influence of the arts on the whole population severely endangered by state indoctrination, which could be unheard of were it not for religious fundamentalism which already knows experiments of similar intensity, if not of the same extent. The Italian humanists themselves appeared (and won) after a much longer period of Christian supremacy, supported by state power and perniciousness, as it seems, for the Christian faith of the day. But dramatic art and literature does not come to the people themselves. There must be connoisseurs, critics, translators, editors, and teachers at all levels of humanities to encourage the reception of the message of the arts and make it accessible to many. In Soviet Russia, which was praised - probably with some right - as the most well read country in the world, literary criticism, being sometimes very monotonous, was active and much appreciated.

Some causes made the exaggeration regarding Soviet readership partly true - the stratum of the reading public was remarkably broad and not as differentiated as it became without Party censorship, which had prohibited much of the good literature and most of the bad. Additional reasons for prolific reading were broad publishing activity directed by the state, inexpensive book production, and the lack of other activities caused 
mostly by social politics and - this time unwittingly thanks to the ideological challenge itself. Scientific socialism and its state politics changed the country into a great reading hall where humanities became very popular.

Without running the danger of wishful construction based on the projection of the most recent ideas into the past, I can state here as a psychological feature of Soviet time that such texts as Characters of Theophrast or characters in Moliere or Shakespeare were considered by the intelligentsia as faintly antisovietical. The reason was not quite clear then, I guess. The effect was caused, however, by an impressive presence of man as he has been and yet is in spite of the ages passing by. One could see that despite the progress celebrated ingenuously by soviet ideology, and for all the Cyclopean experiments of indoctrination, the people were in principle neither better or worse than those described by the great observers of human kind. The humanistic tautology we have spoken of above reveals here one of its facets: man is just as he was.

As free and sometimes even controlled humanities succeeded in showing beyond dispute, humanity did not follow the prescriptions of socialist humanism neither in its good or bad, obviously perennial, habits. The difficulty of morally improving humankind could and probably should provoke a feeling of distress. But for the opponents of communist ideology these facts were felt as reassuring: the claims of ideology are obviously false; the power of the Party is not as great as it assumes.

Christian anthropology is much more adjusted to this state of affairs, professing the fundamental sinfulness and practical incorrigibility of the human race regardless of any social order. This much more adequate model made the Church orthodoxy survive two millenniums confidently, while communism - from the cradle to its death-bed - will hardly last more than two hundred years.

\section{3.}

More inventive, I think, was the thesis, eagerly advocated by communists, that crucial changes of man's conscience and self-understanding have taken place throughout world history. Therefore, they will occur in the future along the lines designed by 'the only one teaching right'. The simplistic ideaof (radical as well as unilinear) progress (invented not by communists, we should add, but handled by them with brave naiveté) was 
a great help in the formation of this utopism. The Soviet pattern of excellence was not even praised as just a next step in the progress of human genius, but as something fundamentally new, while made known through the Revelatio Sancti Caroli Treverensis.

The idea of the inferiority of the past or of the neighboring cultures of the present world brought opposite results: a very popular evaluation of everything foreign as superior to the Soviet. It is remarkable that such socially important convictions could spread rapidly, provided that the broad literary tradition, both of the arts and of the mediating humanities, was at work.

Exegetic help is often necessary, notwithstanding the fact that an immediate impression from many an ancient work of art - let it be a vase-painting or tragic or lascivious literature - shows that there is nothing equal to classical works (of whatever epoch and nation) in their translatability. A wonderful comprehensibility (due more to the damages of tradition than to some intrinsic qualities of the works of art themselves) implies a stupendous underlying continuity in the human experience.

Typically it is ancient literary criticism, which through its often admirable appreciation of classical artistic achievements, shows us the way to an adequate appreciation. This circumstance reinforces the idea of the shared human heritage despite the diversity of social structures and the different levels of civilization. Those who know this can demonstrate to others the basic unity of humankind without any imposture, convicting the rapid and radical transfiguration of Man of being (ideological) utopia.

History as part of humanities studies for the most part reflects institutions and events. Is it legitimate for philology to be regarded as ancilla historiae? Within the limits of a chiefly historical pursuit this is, admittedly, the case: philological skills are instruments and prerequisites for handling the sources fully and safely. Hegel was partly right when he spoke of the aggregate nature of the subject and methods of philology. This is not, however, the end of the story; neither is it the (only) end of philology. Philology takes interest in every outward and inner circumstance of human existence, fussy everyday trifles and sophisticated works of imagination inclusive. Human life is studied by philology in its daily course and in its highest daydreams as well. Its adoration of fiction (see the Defences of Poetry, written by Shelley and Matthew Arnold) is not casual. 
While history investigating the causes and consequences of important events is set in the framework of literary skill and almost inevitable ideological engagement, philology is seemingly preoccupied with detail and is less conscious of its own aims and merits.

Nevertheless, the subject of philology is so immense in its range and importance that philology being the study of styles did not come into its own distinctive style. Neither does philology arrive at any ideological involvement, let it be its own philosophy. This quality is crucial for our scrutiny. Just this apparent absentmindedness and lack of ambition gives philology the privilege to be outside of the pervasive element of ideology. Philology is - on the whole - one of the few ideology-proof elements of culture. This explains the fact felt empirically by many great philologists of the golden periods (these are usually the same as belles-époques of respective countries): somehow, philology is the leader (hegemon again!) of the humanities cycle. Denying the inner unity of philology is therefore not its own fault, but that of the insufficient interpretation of relations in this sphere of knowledge.

The Italian heroes of classical philology were not called humanists in vain: if the classical texts built the body of philology, while its soul was, notoriously, the understanding (Interpretation), then humanistic enthusiasm for the history of human excellence is necessarily its spirit. Providing affluent testimony to what historical man (in his significant achievements) is, humanities - philology ahead - bear witness to the human character attested by history against arbitrary and partial allegations of ideologies.

\section{4.}

An interesting paraphenomenon of any ruling ideology is what we may call counter-ideology (or -ideologies), opposing the predominance of the imperious one. These are more or less contingent configurations of ideas formed or cited as true thanks to the circumstance that they oppose the ideology in command. The process of authorization of counter-ideological arguments is thus highly mechanical; the ideas are most often those of ideologies defeated earlier. All these are of course useful partners during the ideological war against the ideocracy. After the victory these counter-ideologies begin to revitalize each other.

So it is no wonder that many creative spirits tried to find another way around - to slip out from within the 
framework imposed by whatever ideology, as well as functional counter-ideology. Such an out-outsider looked as if there was no such thing as his being a subject of state ideology at all. It was rather a Kunststück: I can relate to many chefs-d'oeuvre of this kind.

There was a custom in Soviet time to decorate streets and houses with portraits of the members of the Politburo during communist festivities. Joseph Brodsky, asked by an acquaintance of his, whose huge portrait adorned the house he lived in, was probably expected to answer: "Gosh, how should I know? Loathsome fellow" or something like that. The poet should have answered, however, in a more exquisite way: "Well, I don't know. It looks very much like William Blake, I daresay".

Such inner emigration was very quiet, but at the same time an effective means to resist the official ideology without a direct confrontation, in order to gain the point safely and slowly. Without such "active passive resistance" (an expression coined by Solzhenitsyn), that is without the praxis of gradually eroding the dominant ideology within oneself and one's environment, the gentle revolution that has taken place at the end of perestroika, would never have happened.

Reverting to our speculation: this manner of denying an aggressive ideology is, of course, absolutely impossible without the help of scholarship, that is, it needs the authoritative presence of humanities. Any educated and spirited investigator writing about letters, who deserves the name, may become one day - as we see - at the greatest moment, a weapon against ideological attempts. Evasive Proteus triumphs over Prometheus; a shepherd boy beats Goliath. Once he achieves his purpose the scholar does not continue to use his humanist subject ideologically, he returns to the genuine, impartial, scholarly study of the bonae litterae. He could not create ideology from philology, even if he could, the ideologyproofness is the most philosophical quality in authentic humanities. Without being a counter-ideology, humanism in the (title) form of philology becomes, under necessity, a marvelous opponent of ideology.

\section{IV.}

Summing up. In the beginning I spoke of the faint contours of humanism, on the one hand, and the strong 
silhouettes of ideology, on the other. Then I established some provinces where humanism and ideology cannot help but clash with each other: though aggressive, humanism proves to be highly combative and even destructive to all those overtly false or simplistic assertions about man that ideologies are naturally inclined to operate with.

Humanism is an enthusiasm for human excellence, remembering human deficiencies; the humanistic search is conducted through the systematic study of classical (ancient or otherwise) literary achievements. Philology as Traditionsforschung does not merely serve the knowledge of its peripeties, but controls whether the continuity of tradition is ensured. An international character of scholarship is a guarantee of the universal range of this mostly prophylactic control.

Being incompatible with ideology, humanism proves to be an effective traditional weapon against any ideological preponderance. As the spirit of humanities and especially of philology, humanism, in one of its capacities, is anti-ideology. This brings one more justification to the exercise of humanities: as knowledge half anonymously responsible for historical anthropology, these would-be uncommitted, seemingly orchidaceous disciplines formed in the solid id est traditional methods of criticism, form an indomitable stronghold able to withstand the attacks of militant - old or new, exiguous or vast - ideologies. The philology is then not only the servant of texts and the treasurer of curiosities, but as required, a defender of uncensored humanity against its impatient and ill-advised advisors. Humanistic scholarship, known of old as an instrument of proven reliability and used in the manifold search for human identity, thus reveals itself at the same time as a tool to defend laboriously found truths from impostors who dare to falsify them by quasi-intellectual procedures.

Alexander K. Gavrilov

St. Petersburg

Accueil Surfaces | Table des matières | Recherche $\underline{\text { Surfaces Home Page | Table of Contents | Search }}$

PUM | Livres | Revues | Publications électroniques | Vente et distribution 